\title{
A Framework for Assessing Water and Proppant Use and Flowback Water Extraction Associated with Development of Continuous Petroleum Resources
}

The U.S. Geological Survey (USGS) is developing approaches for the quantitative assessment of water and proppant involved with possible future production of continuous petroleum deposits. The assessment approach is an extension of existing USGS petroleum-assessment methods, and it aims to provide objective information that helps decision makers understand the tradeoffs inherent in resource-development decisions. This fact sheet provides an overview of USGS assessments for quantities of water and proppant required for drilling and hydraulic fracturing and for flowback water extracted with petroleum; the report also presents the form of the intended assessment output information.

\section{Background}

Continuous petroleum resources (including the oil-rich Bakken Formation of North Dakota and Montana, and the gas-rich Marcellus and Barnett Formations in the Appalachian Basin and in Texas, respectively) are the target of rapidly increasing development in the United States. These production booms represent important contributions to the Nation's energy portfolio, but they have also led to new public concerns regarding the effects of petroleum production on other resources and to a suite of new questions to be considered by decision makers in the public and private sectors.

The majority of emerging questions regarding petroleum development involve the two technologies that make this development possible: highprecision horizontal drilling and highly effective multistage hydraulic fracturing. The drilling process can require several hundred thousand gallons of water for use in the drilling mud that removes rock cuttings from the borehole and cools the drill bit (Chesapeake Energy, 2012; Clark and others, 2013). Hydraulic fracturing requires between hundreds of thousands and several million gallons of water, along with hundreds or thousands of tons of proppant (typically sand) and lesser quantities of various

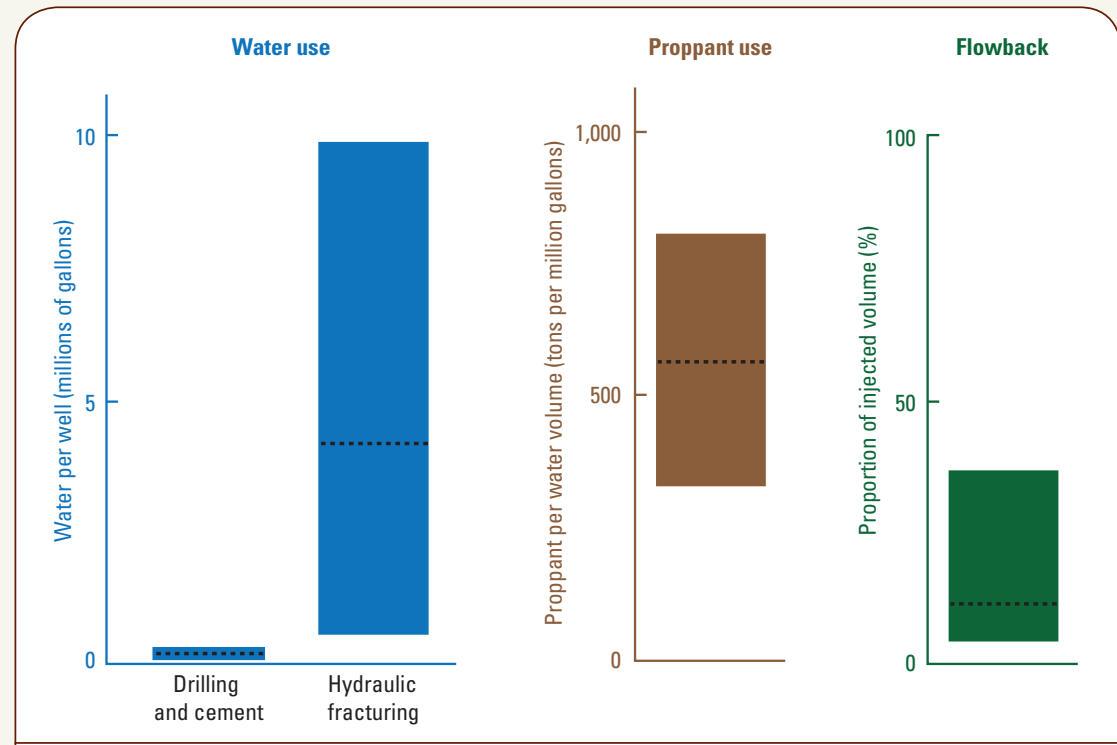

How Much?

Quantities of water and proppant used per well, and flowback water extracted, vary within continuous resource development areas, and across the Nation. These plots show estimated ranges for each quantity for continuous petroleum development throughout the United States, based on data from Nicot and Scanlon (2012) and Clark and others (2013), and from the North Dakota Industrial Commission, Oil and Gas Division. The colored bars represent ranges of published or available values, discounting outliers, and the dashed black line represents an estimated mean of published or available values. Proppant use is indicated relative to the volume of hydraulic fracturing water because the two are closely related.

Oil well site in Parshall, North Dakota.

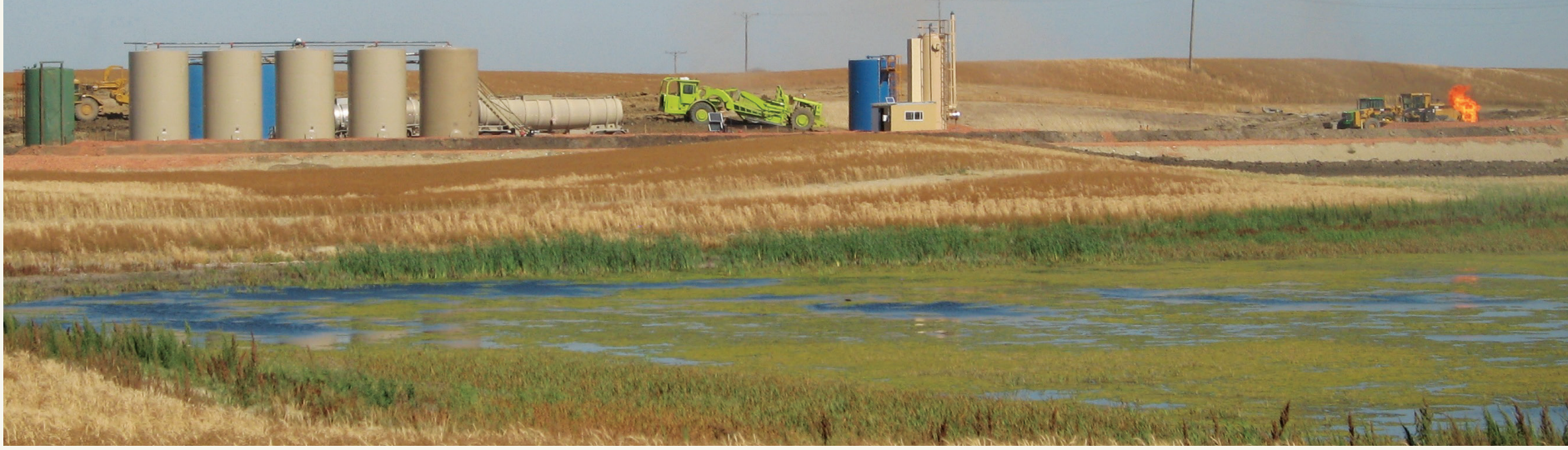




\section{Terminology}

- USGS petroleum assessments: Probabilistic, geologybased studies that estimate the quantity of undiscovered, technically recoverable petroleum resources in a given area. The assessment methodology is rigorously reviewed and aims to provide robust, repeatable results. Methodology, examples, and more information can be found at: http://energy.usgs.gov/OilGas/AssessmentsData/ NationalOilGasAssessment.aspx and http://energy.usgs.gov/ OilGas/AssessmentsData/WorldPetroleumAssessment.aspx.

- Technically recoverable: Resources in accumulations that are producible using current recovery technology, without reference to economic profitability.

- Continuous petroleum resources: Petroleum accumulations, such as shale petroleum, coalbed natural gas, and tight oil/gas, that are not held in place by geologic traps and the buoyancy of oil and gas relative to water.

- Produced water: Any water that flows out of a well during petroleum production; this includes flowback water, formation brine, and sometimes also aqueous fluids condensed from the gas phase; this may also be called "co-produced water."

- Flowback water: Water injected during hydraulic fracturing that is extracted during petroleum production, mainly during the first several weeks or months after hydraulic fracturing. In produced water samples, it is difficult to distinguish between flowback water and formation brine, so for assessment purposes, we define flowback water as the volume of water that exceeds the baseline water/petroleum production ratio (determined through analysis of well production data).

- Formation brine/water: Water, generally of brackish to brine salinity, that occurs naturally in geologic formations; the term is most often applied to water in petroleum reservoirs.

- Proppant: Granular material, typically sand, used to hold open fractures created during hydraulic fracturing.

chemicals, which are pumped into the shale formation in order to fracture the reservoir and facilitate petroleum flow. Water for drilling and hydraulic fracturing is typically sourced locally due to transportation logistics. Water withdrawals are often from the same regional surface water and groundwater sources that provide water for domestic, agricultural, and industrial use, but water scarcity and technological improvements have led to increased use of brackish groundwater and recycled produced water in some areas (Nicot and Scanlon, 2012). The majority of proppant is sand, and quality requirements (grain size, shape, and strength) dictate that the bulk of proppant sand used in the United States originates from just a few locations in the country (Dolley, 2010; Parsen and Zambito, 2014). Transportation options vary, but typically both water and proppant reach the drill pad by truck. This presents logistical considerations for operators and municipalities due to the large volumes of water and proppant that are injected.

When petroleum production commences, water is extracted from the well along with petroleum. This produced water must be disposed of (often by injection into deep brackish aquifers) or it may be treated, transported, and reused at another well. Estimates of the proportion of hydraulic fracturing water that emerges as flowback water range from 5 to 40 percent of the injected volume. It is possible to assess the quantity of flowback water or produced water (or both), but we focus here on flowback water because it dominates the produced water during the first weeks or months of production and requires particular storage, transportation, and disposal/treatment considerations.

Since the time of its inception, the USGS has provided objective scientific appraisals of the Nation's natural resources, including assessments of petroleum resources (see "Terminology" inset box). In order to support more broadly informed decision making, the USGS is currently developing complementary approaches for quantifying the effects of energy and mineralresource development and use (U.S. Geological Survey, 2007; Ferrero and others, 2013; Haines and others, 2014). In this fact sheet, we present a framework for assessing the quantities of water used for drilling and hydraulic fracturing, proppant used for hydraulic fracturing, and flowback water extracted after petroleum production begins. We also present the form of the fundamental assessment output information; that is, a set of tables that convey the key results.

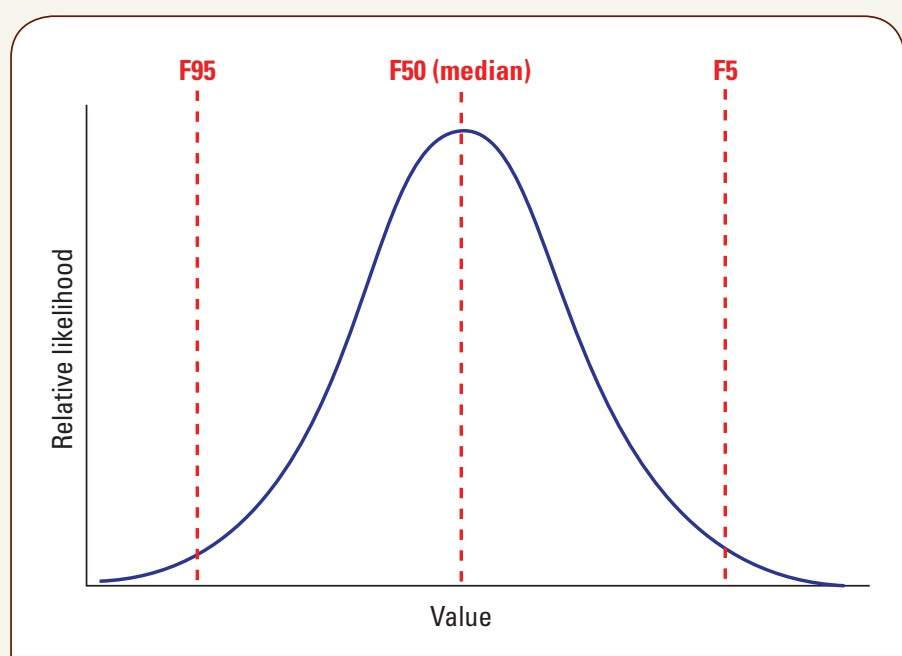

\section{Probability Density Functions}

When estimating an unknown value, a probability density function (PDF) is commonly used to convey the uncertainty in the estimate. Whereas a single value would imply 100 -percent certainty, a PDF indicates the range of possible values and also the relative likelihood of any specific value being "correct." Fractiles are individual values from the PDF, and selected fractiles are commonly used to convey salient details of the distribution; here the 95th, 50th, and 5th fractiles are labeled. There is a 95 percent probability that the true value is greater than the 95th fractile (F95) value. Because the PDF shown here is symmetrical, the mean and the median are equivalent and the $\mathrm{F} 95$ and $\mathrm{F} 5$ values are equidistant from the $F 50$ value. 


\begin{tabular}{|c|c|c|c|c|c|c|c|c|c|c|c|c|c|c|c|c|c|}
\hline \multirow{3}{*}{$\begin{array}{l}\text { Total Petroleum Systems } \\
\text { (TPS) } \\
\text { and Assessment Units (AU) }\end{array}$} & \multirow{3}{*}{$\begin{array}{l}\text { Field } \\
\text { type }\end{array}$} & \multicolumn{16}{|c|}{ Total resource co-requirements/co-production } \\
\hline & & \multicolumn{4}{|c|}{$\begin{array}{l}\text { Water for drilling } \\
\text { (Mgal) }\end{array}$} & \multicolumn{4}{|c|}{$\begin{array}{c}\text { Water for } \\
\text { hydraulic fracturing } \\
\text { (Maal) }\end{array}$} & \multicolumn{4}{|c|}{$\begin{array}{c}\text { Proppant for } \\
\text { hydraulic fracturing } \\
\text { (tons) }\end{array}$} & \multicolumn{4}{|c|}{$\begin{array}{l}\text { Flowback water } \\
\text { (Mgal) }\end{array}$} \\
\hline & & F95 & F50 & F5 & Mean & F95 & F50 & F5 & Mean & F95 & F50 & F5 & Mean & F95 & F50 & F5 & \\
\hline \multicolumn{18}{|l|}{ TPS } \\
\hline AU 00000001 & $\begin{array}{l}\text { Oill } \\
\text { Gas }\end{array}$ & $\mathrm{x}$ & $\mathrm{x}$ & $\mathrm{x}$ & $\mathrm{x}$ & $\mathrm{x}$ & $\mathrm{x}$ & $\mathrm{x}$ & $\mathrm{x}$ & $\mathrm{x}$ & $\mathrm{x}$ & $\mathrm{x}$ & $\mathrm{x}$ & $\mathrm{x}$ & $\mathrm{x}$ & $\mathrm{x}$ & $\mathrm{x}$ \\
\hline AU 00000002 & $\begin{array}{l}\text { Oill } \\
\text { Gas }\end{array}$ & $\mathrm{x}$ & $\mathrm{x}$ & $\mathrm{x}$ & $\mathrm{x}$ & $\mathrm{x}$ & $\mathrm{x}$ & $\mathrm{x}$ & $\mathrm{x}$ & $\mathrm{x}$ & $\mathrm{x}$ & $\mathrm{x}$ & $\mathrm{x}$ & $\mathrm{x}$ & $\mathrm{x}$ & $\mathrm{x}$ & $\mathrm{x}$ \\
\hline AU 00000003 & $\begin{array}{l}\text { Oil/ } \\
\text { Gas }\end{array}$ & $\mathrm{x}$ & $\mathrm{x}$ & $\mathrm{x}$ & $\mathrm{x}$ & $\mathrm{x}$ & $\mathrm{x}$ & $x$ & $\mathrm{x}$ & $\mathrm{x}$ & $\mathrm{x}$ & $x$ & $x$ & $x$ & $x$ & $x$ & $\mathrm{x}$ \\
\hline $\begin{array}{l}\text { Total Co-requirement/ } \\
\text { Co-production }\end{array}$ & & & & & $\mathbf{x}$ & & & & $\mathbf{x}$ & & & & $\mathrm{x}$ & & & & $\mathbf{X}$ \\
\hline
\end{tabular}

Figure 1. The first of four assessment output tables shows key values (fractiles) from the estimates of water and proppant required, and

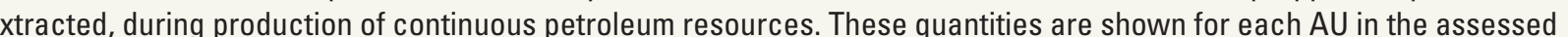
area, and AUs are listed within each assessed TPS. Units of measure for water are millions of gallons (Mgal) and for proppant are metric tons.

\section{Assessing Water and Proppant}

Requirements and Flowback Volume

Existing geology-based USGS petroleum-assessment methods for continuous deposits (Schmoker, 2005; Charpentier and Cook, 2010) provide the foundation for quantifying the approach begins with identification of geologically defined to (TPS) that include the elements necined to for a viable petrolum resource: source rock, reservocessack, and conditions and timing sitable for both the cotion pring of petrolum. Within each TPS, assess determine geologically defined assessment units (AUs). With. ach $\mathrm{AU}$, n number of input a a a drain, are of me recovery of petroleum per well, and the percentage of the untested part of the $\mathrm{AU}$ that contins undiscovered petroleum These estimates are based on available data from the specific area being studied or from geologically similar areas that are used as analogs. Estimates are defined probabilistically as probability density functions (PDF) in order to convey the inherent uncertainty (see inset box "Probability Density Functions"). The input data are combined with a Monte Carlo algorithm tha constructs tens of thousands of simulations to determine probbilistic estimates of the quantity of undiscovered, technically recoverable, petroleum resource in each AU. Many examples of USGS petroleum assessments (including maps of TPS and AUs, output tables, and supporting data) may be found at the websites noted in the "Terminology" box. One key consideration with

Figure 2. The second of the four assessment output tables provides information regarding past drilling rates and water and proppant requirements associated with various possible future drilling rates. Tabulated water requirements include use for drilling and for hydraulic fracturing. Units of measure for water are Mgal (millions of gallons) and units for proppant are metric tons.

the results of USGS petroleum asse

shows the total of each of these assessed quantities for all of the
AUs in the study area. As for the associated petroleum assessAust, the se de

are linked to the pers petrolum ressoure and do not specify when, whether, or how rapidly the petroleum resource will be developed As such, the proppant- and water-assessment data correspond with development of the entire undiscovered petroleum resource and do not indicate the rate or timing of demand and flowback water extraction. Furthermore, any estimates of future drilling rate are inherently speculative and cannot be derived from USGS assessment information. To provide a context for analysis of questions that relate to the rate of petroleum development, we provide a second table (fig. 2) that shows, for each AU, the number of wells drilled in recent years and the water usage corresponding with four possible annual drilling rates that are intended to span the range of future possibilities.

For some questions, the water-requirement estimates are meaningful mainly in the context of the regional hydrologic system. The third output table (fig. 3) shows data on surface water and groundwater, precipitation, and water use in order to provide context for the potential future water usage indicated by the table in figure 2. The specific information provided in this third output table will vary between assessment locations base on data availability and on relevant comparison metrics. The geographic areas for which to calculate and display this information may also vary between assessment locations; AUs may not always be the most helpful or relevant option, particularly in cases with complex overlapping AU relationships. In genera for each $\mathrm{AU}$, we will provide surface water and groundwate withdrawals (for example, available from Kenny and others, 2009), stream flow (available from $h$ ttp://waterwatch.usgs.gov/, and annual precipitation averages (available from the USGS's Geo Data Portal, $h t t p: / / c i d a . u s g s . g o v / c l i m a t e / g d p /$, described by Blodgett and others, 2011). For further comparison and contex, the table also includes withdrawals by water-use categories relevant to the particular study location, such as agriculture, industry, thermoelectric, and municipal (available from Kenny

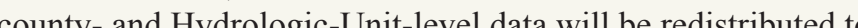

the AU boundaries. Local/regional comparison quantities are not provided for proppant because it is generally sourced on national scale.

Many water and proppant questions relate to comparisons between AUs and between study areas, across the Nation, an around the world. A sumity output table (fig. 4) provides simple comparison metrics to address these questions: water required per unit of petroleum (oil or gas), proppant required per unit of petroleum, and flowback water volume per unit of petroleum. This information may be provided for multiple forms of petroleum (for example, natural gas and natural gas liquids) as relevant for a particular study. For completeness, the summary output table also shows the mean value of the total petroleum in each $\mathrm{AU}$, and for simplicity and ease of comparison, all of the quantities are calculated based on mean values of the associated PDFs. The final row of this table shows the weighted mean values across all AUs in the TPS. This is calculated by dividing the sum of the mean values for all AUs by the sum of the mean total petroleum for all AUs.

\section{Applications}

The described assessments of (1) water and proppant requirements related to petroleum development and (2) flowback water volume are intended to provide objective, broadscope information to address a range of resource availability land use, and resource-conflict questions and concerns. The assessment results will inform decisions involving regional denand and disposal and will facillate regional infastructure planning. In addition, the results will enable informed analysis various development schemes for a including comparison of vains development sches for a given region and comparison of different regions for the potential development of a given and proppant but these numbers can readily be converted to

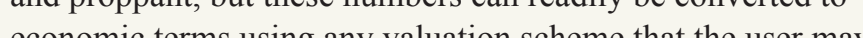
choose. For each asesm valuation scheme hat the user may presented in a fact sheet contining tables such as those will be prese These fact sheets will be accompnied by publicatiown provide suppoting information regring the ase data and the study area.

\begin{tabular}{|c|c|c|c|c|c|c|c|c|c|c|c|c|c|c|c|c|c|c|}
\hline \multirow{3}{*}{$\begin{array}{l}\text { Total Petroleum Systems } \\
\text { (TPS) } \\
\text { and Assessment Units (AU) }\end{array}$} & \multirow{3}{*}{$\begin{array}{l}\text { Field } \\
\text { type }\end{array}$} & \multicolumn{5}{|c|}{$\begin{array}{c}\text { Historical drilling } \\
\text { (number of wells drilled each year) }\end{array}$} & \multicolumn{12}{|c|}{ Co-requirements and co-production for various possible annual drilling totals } \\
\hline & & \multirow[b]{2}{*}{2008} & \multirow[b]{2}{*}{2009} & \multirow[b]{2}{*}{2010} & \multirow[b]{2}{*}{2011} & \multirow[b]{2}{*}{2012} & \multicolumn{3}{|c|}{10 wells } & \multicolumn{3}{|c|}{100 wells } & \multicolumn{3}{|c|}{1,000 wells } & \multicolumn{3}{|c|}{5,000 wells } \\
\hline & & & & & & & $\begin{array}{l}\text { Required } \\
\text { water } \\
\text { (Mgal) }\end{array}$ & $\begin{array}{c}\text { Required } \\
\text { proppant } \\
\text { (tons) }\end{array}$ & $\begin{array}{c}\text { Flowback } \\
\text { water } \\
\text { (Mgal) }\end{array}$ & $\begin{array}{l}\text { Required } \\
\text { water } \\
\text { (Mgal) }\end{array}$ & $\begin{array}{c}\text { Required } \\
\text { proppant } \\
\text { (tons) }\end{array}$ & $\begin{array}{c}\text { Flowback } \\
\text { water } \\
\text { (Mgal) }\end{array}$ & $\begin{array}{c}\text { Required } \\
\text { water } \\
\text { (Mgal) }\end{array}$ & $\begin{array}{c}\text { Required } \\
\text { proppant } \\
\text { (tons) }\end{array}$ & $\begin{array}{c}\text { Flowback } \\
\text { water } \\
\text { (Mgal) }\end{array}$ & $\begin{array}{l}\text { Required } \\
\text { water } \\
\text { (Mgal) }\end{array}$ & $\begin{array}{c}\text { Required } \\
\text { proppant } \\
\text { (tons) }\end{array}$ & $\begin{array}{l}\text { Flowback } \\
\text { water } \\
\text { (Mgal) }\end{array}$ \\
\hline \multicolumn{19}{|l|}{ TPS } \\
\hline AU 00000001 & $\begin{array}{l}\text { oil/ } \\
\text { Gis }\end{array}$ & $\mathrm{x}$ & $\mathrm{x}$ & $\mathrm{x}$ & $\mathrm{x}$ & $\mathrm{x}$ & $\mathrm{x}$ & $\mathrm{x}$ & $\mathrm{x}$ & $\mathrm{x}$ & $\mathrm{x}$ & $\mathrm{x}$ & $\mathrm{x}$ & $\mathrm{x}$ & $\mathrm{x}$ & $\mathrm{x}$ & $\mathrm{x}$ & $\mathrm{x}$ \\
\hline AU 00000002 & $\begin{array}{l}\text { oil/ } \\
\text { Gas }\end{array}$ & $\mathrm{x}$ & $\mathrm{x}$ & $\mathrm{x}$ & $\mathrm{x}$ & $\mathrm{x}$ & $\mathrm{x}$ & $\mathrm{x}$ & $\mathrm{x}$ & $\mathrm{x}$ & $\mathrm{x}$ & $\mathrm{x}$ & $\mathrm{x}$ & $\mathrm{x}$ & $\mathrm{x}$ & $\mathrm{x}$ & $\mathrm{x}$ & $\mathrm{x}$ \\
\hline AU 00000003 & $\begin{array}{l}\text { oill } \\
\text { Gas }\end{array}$ & $\mathrm{x}$ & $\mathrm{x}$ & $\mathrm{x}$ & $\mathrm{x}$ & $\mathrm{x}$ & $\mathrm{x}$ & $\mathrm{x}$ & $\mathrm{x}$ & $\mathrm{x}$ & $x$ & $x$ & $x$ & $x$ & $x$ & $x$ & $x$ & $x$ \\
\hline Total & & $x$ & $x$ & $x$ & $x$ & $x$ & $x$ & $x$ & $x$ & $\mathbf{x}$ & $\mathbf{x}$ & $\mathbf{x}$ & $x$ & $\mathbf{x}$ & $\mathbf{x}$ & $\mathbf{x}$ & $x$ & $x$ \\
\hline
\end{tabular}




\begin{tabular}{|c|c|c|c|c|c|c|c|c|c|}
\hline \multirow[b]{2}{*}{$\begin{array}{l}\text { Total Petroleum Systems } \\
\text { (TPS) } \\
\text { and Assessment Units (AU) }\end{array}$} & \multirow[b]{2}{*}{$\begin{array}{l}\text { Field } \\
\text { type }\end{array}$} & \multicolumn{2}{|c|}{ Surface water } & \multirow[b]{2}{*}{$\begin{array}{c}\text { Groundwater } \\
\text { Withdrawal } \\
\text { (annual total, } \\
\text { 2005) } \\
\text { (Mgal) } \\
\end{array}$} & \multirow[b]{2}{*}{$\begin{array}{l}\text { Precipitation } \\
\text { (average annual, } \\
\text { 2003-2013) } \\
\text { (Mgal) }\end{array}$} & \multicolumn{4}{|c|}{ Water use (annual total, 2005) } \\
\hline & & \begin{tabular}{|c} 
Flow \\
(average annual, \\
2003-2013) \\
(Mgal)
\end{tabular} & \begin{tabular}{|c|} 
Withdrawal \\
(annual total, \\
2005) \\
(Mgal) \\
\end{tabular} & & & $\begin{array}{l}\text { Agriculture } \\
\text { (Mgal) }\end{array}$ & $\begin{array}{l}\text { Industry } \\
\text { (Mgal) }\end{array}$ & $\begin{array}{c}\text { Municipal } \\
\text { (Mgal) }\end{array}$ & $\begin{array}{l}\text { Other } \\
\text { (Mgal) }\end{array}$ \\
\hline \multicolumn{10}{|l|}{ TPS } \\
\hline AU 00000001 & $\begin{array}{l}\text { Oil/ } \\
\text { Gas }\end{array}$ & $x$ & $x$ & $x$ & $x$ & $x$ & $x$ & $x$ & $x$ \\
\hline AU 00000002 & $\begin{array}{l}\text { Oil/ } \\
\text { Gas }\end{array}$ & $x$ & $x$ & $x$ & $x$ & $x$ & $x$ & $x$ & $x$ \\
\hline AU 00000003 & $\begin{array}{l}\text { Oil/ } \\
\text { Gas }\end{array}$ & $x$ & $x$ & $x$ & $x$ & $x$ & $x$ & $x$ & $x$ \\
\hline Total & & & $\mathrm{x}$ & $\mathrm{x}$ & $\mathbf{x}$ & $\mathrm{x}$ & $\mathrm{x}$ & $\mathbf{x}$ & $\mathrm{x}$ \\
\hline
\end{tabular}

Figure 3. The third of four assessment output tables provides, for context and comparison, volumes of water in various parts of the regional hydrologic system: surface water and groundwater, precipitation, and water use. This example table shows values per AU, but other geographic divisions are possible and may be particularly relevant for studies with many overlapping AUs. Units of measure for water are Mgal (millions of gallons).

\begin{tabular}{|c|c|c|c|c|c|}
\hline $\begin{array}{l}\text { Total Petroleum Systems } \\
\text { (TPS) } \\
\text { and Assessment Units (AU) }\end{array}$ & $\begin{array}{l}\text { Field } \\
\text { type }\end{array}$ & $\begin{array}{c}\text { Total } \\
\text { undiscovered } \\
\text { petroleum } \\
\text { (MMBO or BCFG) } \\
\text { Mean }\end{array}$ & $\begin{array}{c}\text { Water } \\
\text { per oil/gas } \\
\text { (Mgal/MMBO } \\
\text { or Mgal/BCFG) } \\
\text { Mean }\end{array}$ & 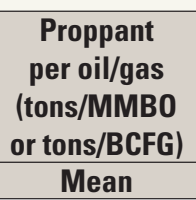 & $\begin{array}{c}\text { Flowback water } \\
\text { per oil/gas } \\
\text { (Mgal/MMBO } \\
\text { or Mgal/BCFG) } \\
\text { Mean }\end{array}$ \\
\hline \multicolumn{6}{|l|}{ TPS } \\
\hline AU 00000001 & $\begin{array}{l}\text { Oil/ } \\
\text { Gas }\end{array}$ & $\mathrm{x}$ & $\mathrm{x}$ & $\mathrm{x}$ & $\mathrm{x}$ \\
\hline AU 00000002 & $\begin{array}{l}\text { Oil/ } \\
\text { Gas }\end{array}$ & $x$ & $x$ & $x$ & $x$ \\
\hline AU 00000003 & $\begin{array}{l}\text { Oil/ } \\
\text { Gas }\end{array}$ & $x$ & $\mathrm{x}$ & $x$ & $\mathrm{x}$ \\
\hline Weighted Mean & & & $x$ & $x$ & $\mathbf{x}$ \\
\hline
\end{tabular}

Figure 4. The fourth of four assessment output tables shows the mean water and proppant requirements and flowback water volume per unit of petroleum in MMBO (million barrels of oil) or BCFG (billion cubic feet of gas), along with the mean total undiscovered petroleum (from the corresponding USGS petroleum assessment). Units of measure for water are Mgal (millions of gallons) and for proppant are metric tons.

The numbers provided in the assessment output tables represent the fundamental parts of a simple water budget (Healy and others, 2007) and can be used for regional-scale analyses. The assessment results are not directly suitable for incorporation into numerical water models because they lack spatial and temporal specificity, but the numbers can help inform surfacewater- and groundwater-modeling efforts. It is beyond the scope of this type of assessment work to predict exact withdrawal rates at specific geographic locations, and the described assessment results represent the best information that can be drawn from USGS petroleum-assessment results. Water modelers can estimate withdrawal rates for their models using the information in the second output table and any other available data regarding future petroleum development trends. All USGS assessment data, including AU boundaries, are publicly available, and end users of assessment information may incorporate the AUspecific quantities with other geographic data, such as aquifer or surface-water drainage boundaries, to estimate water and proppant information specific to geographic areas of interest.

The assessment approach includes no assumptions regarding the source or characteristics of required water or proppant, or the fate of flowback water. As such, planners may incorporate knowledge of prevailing sourcing and disposal/ treatment trends to understand the implications of various petroleum-development scenarios. Alternatively, planners may use the assessment information to compare sourcing and disposal options, such as the use of fresh versus brackish water for hydraulic fracturing, the use of ceramic versus sand proppant, and the disposal versus treatment and re-use of flowback water. 


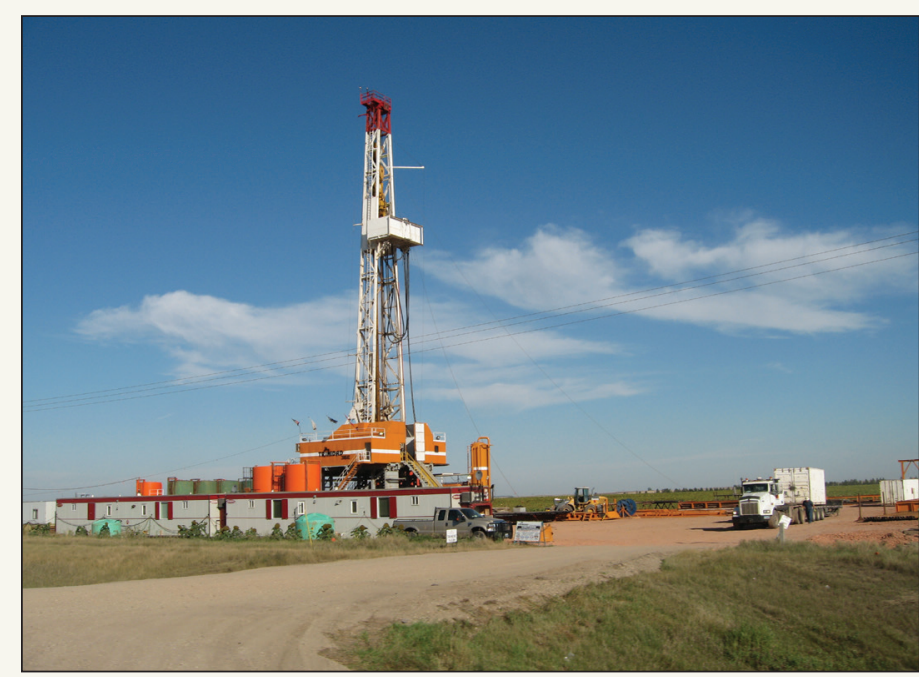

Drill rig near Parshall, North Dakota.

\section{References Cited}

Blodgett, D.L., Booth, N.L., Kunicki, T.C., Walker, J.L., and Viger, R.J., 2011, Description and testing of the Geo Data Portal-Data integration framework and Web processing services for environmental science collaboration:

U.S. Geological Survey Open-File Report 2011-1157, 9 p., http://pubs.usgs.gov/of/2011/1157/.

Charpentier, R.R., and Cook, T.A., 2010, Improved USGS methodology for assessing continuous petroleum resources: U.S. Geological Survey Data Series 547, 22 p. and program, http://pubs.usgs.gov/ds/547/.

Chesapeake Energy, 2012, Water use in Niobrara Deep Shale Gas Exploration: Chesapeake Energy Fact Sheet, 2 p., accessed January 27, 2014 at http://www.chk.com/media/ educational-library/fact-sheets/niobrara/niobrara_water use_fact_sheet.pdf.

Clark, C.E., Horner, R.M., and Harto, C.B., 2013, Life cycle water consumption for shale gas and conventional natural gas: Environmental Science and Technology, v. 47, p. 11,829-11,836.

Dolley, T.P., 2012, Silica, in 2010 minerals yearbook: U.S. Geological Survey, 17 p., http://minerals.usgs.gov/ minerals/pubs/commodity/silica/myb1-2010-silic.pdf.

Ferrero, R.C., Kolak, J.J., Bills, D.J., Bowen, Z.H., Cordier, D.J., Gallegos, T.J., Hein, J.R., Kelley, K.D., Nelson, P.H., Nuccio, V.F., Schmidt, J.M., and Seal, R.R., 2013, U.S. Geological Survey energy and minerals science strategy_A resource lifecycle approach: U.S. Geological Survey Circular 1383-D, 37 p., http://pubs.usgs.gov/ circ/1383d/.
Haines, S.S., Diffendorfer, J.E., Balistrieri, Laurie, Berger, Byron, Cook, Troy, DeAngelis, Don, Doremus, Holly, Gautier, D.L., Gallegos, Tanya, Gerritsen, Margot, Graffy, Elisabeth, Hawkins, Sarah, Johnson, K.M., Macknick, Jordan, McMahon, Peter, Modde, Tim, Pierce, Brenda, Schuenemeyer, J.H., Semmens, Darius, Simon, Menjamin, Taylor, Jason, and Walton-Day, Katie, 2014, A framework for quantitative assessment of impacts related to energy and mineral resource development: Natural Resources Research, v. 23, no. 1, p. 3-17. DOI: 10.1007/s11053-013-9208-6.

Healy, R.W., Winter, T.C., LaBaugh, J.W., and Franke, O.L., 2007, Water budgets - Foundations for effective water-resources and environmental management: U.S. Geological Survey Circular 1308, 90 p., http://pubs.usgs.gov/circ/2007/1308/.

Kenny, J.F., Barber, N.L., Hutson, S.S., Linsey, K.S., Lovelace, J.K., and Maupin, M.A., 2009, Estimated use of water in the United States in 2005: U.S. Geological Survey Circular 1344, 52 p., http://pubs.usgs.gov/circ/1344/.

Nicot, J.P., and Scanlon B.R., 2012, Water use for shale-gas production in Texas: U.S. Environmental Science and Technology, v. 46 , p. $3,580-3,586$.

Parsen, M., and Zambito, Jay, 2014, Frac sand in Wisconsin: Madison, Wisc., Wisconsin Geological and Natural History Survey, Fact Sheet 05, accessed February 13, 2014 at http:// wisconsingeologicalsurvey.org/pdfs/frac-sand-factsheet.pdf.

Schmoker, J.W., 2005, U.S. Geological Survey assessment concepts for continuous petroleum accumulations, chap. 13 of U.S. Geological Survey Southwestern Wyoming Assessment Team, Petroleum systems and geologic assessment of oil and gas in the southwestern Wyoming province, Wyoming, Colorado, and Utah: U.S. Geological Survey Digital Data Series DDS-69-D, http://certmapper.cr.usgs.gov/data/noga00/natl/text/CH_13.pdf.

U.S. Geological Survey, 2007, Facing tomorrow's challengesU.S. Geological Survey science in the decade 2007-2017: U.S. Geological Survey Circular 1309, 70 p., http://pubs.usgs.gov/ circ/2007/1309/.

—By Seth S. Haines, Troy A. Cook, Joanna N. Thamke, Kyle W. Davis, Andy J. Long, Richard W. Healy, Sarah J. Hawkins, and Mark A. Engle

For additional information contact:

Seth Haines

U.S. Geological Survey

Box 25046, MS 939

Denver Federal Center

Denver, C0 80225-0046

shaines@usgs.gov

ISSN 2327-6916 (print)

ISSN 2327-6932 (online)

http://dx.doi.org/10.3133/fs20143010 